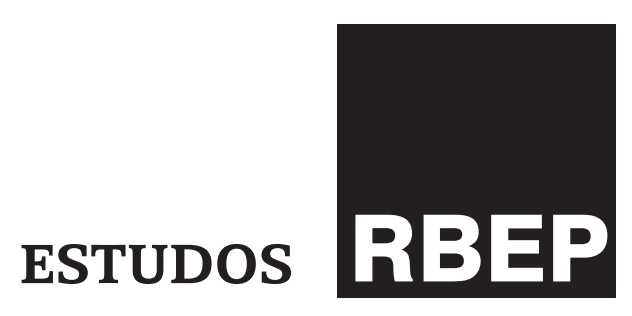

\title{
Educational Standards and Australia: a changed landscape
}

Phil Lambert ${ }^{\mathrm{t}, \text { II }}$

http://dx.doi.org/10.1590/S2176-6681/291437381

University of Sidney,

Sidney, Australia. E-mail:

$<$ phillambertconsulting@ gmail.com>; <http://orcid. org/0000-0001-9214-0147>.

\begin{abstract}
This article provides insight into the development of Australia's educational standards, the resultant alignment between curriculum, assessment and teaching standards and the move to online tailored testing. Background to the development and nature of the standards is provided as well as areas being considered for further reform. The article acknowledges the challenges in reaching settlement in relation to the standards-setting reforms in a Federation such as Australia. It also outlines the significant benefits now being realised as a result of the collaborative effort to achieve a national curriculum, a national assessment program and national teaching standards.
\end{abstract}

Keywords: Educational standards; assessment; curriculum. 


\section{Resumo}

\section{Padrões educacionais e a Austrália: mudança de cenário}

Este artigo traz perspectivas sobre o desenvolvimento dos padrões educacionais na Austrália, que resultou de um alinhamento do currículo, da avaliação e dos padrões de ensino e da mudança para um teste online adaptado. Fornece-se um histórico da evolução e da natureza dos padrões, bem como das áreas que estão sendo consideradas para futuras reformas. Reconhecem-se os desafios encontrados para se chegar a um acordo em relação às reformas que estabelecem normas em uma Federação como a australiana. Descrevem-se ainda os significativos benefícios que se percebe agora como resultado de um esforço colaborativo para se chegar a um currículo nacional, a um programa de avaliação nacional e a padrões nacionais de ensino.

Palavras-chave: padrões educacionais; avaliação; currículo.

The endorsement of the Australian Curriculum in October 2015 by the Council of Australian Education Ministers (known as the Education Council) was a significant step taken in Australian education history. This decision established for Australia its first national curriculum.

Australia like a number of other countries, including Brazil, is a federation of states (and territories) ${ }^{1}$. While there has been a commitment by the Australian states and territories since Federation ${ }^{2}$ to collaborate on matters of national importance there are several areas where development of a national approach has been difficult to progress or achieve. Education, until recent times, has been one of these areas.

Education (and specifically schooling) in Australia is primarily a State responsibility. However, the ground-breaking Melbourne Declaration on Educational Goals for Young Australians endorsed by education ministers in 2008 set both a vision and an explicit agenda for key reforms aimed at establishing teaching standards, curriculum content standards and student performance standards for the country. The Melbourne Declaration, as it is most often called, changed Australia's educational landscape forever.

The national architecture formed to develop the standards, the Australian Curriculum, Assessment and Reporting Authority (Acara) and the Australian Institute for Teaching and School Leadership (AITSL), commenced their tasks in 2008 and 2010 respectively.

The work that has taken place since 2008 has resulted in the development and endorsement of:

- A comprehensive and contemporary national curriculum, inclusive of subject area content, general capabilities (sometimes referred to as $21^{\text {st }}$ Century skills) and cross-curriculum priority areas aimed

\footnotetext{
Territories in Australia are separate jurisdictional federal territories that in many respects administer policy and operational responsibilities in areas such as education and health in the same way states fulfil their responsibilities in these areas.

2 Australia became a nation through the formal Federation of six former British colonies on 1 January 1901.
} 
at equipping students for the current and anticipated issues facing Australia;

- Professional teaching standards that set out what is expected of teachers in their practice across three domains (professional knowledge, professional practice and professional engagement) and across four career stages of teaching (graduate, proficient, highly accomplished and lead); and

- A national assessment and reporting regime that enables teachers, students, parents and the community to have transparent information about the performance of students and schools in relation to achievement standards and national benchmarks in literacy and numeracy.

While a national assessment regime was in place before the above actions, the alignment between the standards is now being fully realised. Prior to the development of the national curriculum full population testing of the country's students in years 3, 5, 7 and 9 was based on prior agreements that had been reached between state and territory officials regarding the scope and nature of test items in literacy and numeracy content. This year sees the direct alignment between the national curriculum learning areas of English and Mathematics and the items to be tested in the National Assessment Program in Literacy and Numeracy (Naplan).

In addition to Naplan relevant content from the Science, Technologies (and the ICT general capability) learning areas and Civics and Citizenship subject area is also being used as the basis for test items in Australia's sample testing program. This testing program, which is held on a rolling three-year basis for each of these areas, acquires information about the performance of Australian students from randomly selected schools. The information obtained from the sample is primarily used to gauge progress in learning in science literacy, ICT literacy and understandings in relation to civics and citizenship. The data are also used to determine where increased attention needs to be applied in relation to teachers' professional development programs and, as a consequence, to their teaching in classrooms. Some initial discussions have been held about extending the sampling program into other subject areas including History, Geography and in some of the general capabilities such as critical and creative thinking, and intercultural understanding.

\section{The Australian Curriculum}

The Australian Curriculum ${ }^{3}$ has been described as three-dimensional in structure. This structure is based on eight learning areas, seven general capabilities and three cross-curriculum priorities.

- The prime structural dimension is the eight learning areas:

- English; http://www.australian curriculum.edu.au 
- Mathematics;

- Science;

- Humanities and Social Sciences (including the subject areas of History, Geography, Civics and Citizenship and Economics and Business);

- Health and Physical Education;

- Languages (with 14 different foreign language curricula, a framework for over 250 Aboriginal languages and Torres Strait Islander languages and three other languages currently being finalised);

- Technologies (including the subject areas of Design and Technology and Digital Technologies); and

- The Arts (including the subject areas of Dance, Drama, Media Arts, Music and Visual Arts).

Embedded in the content of these learning areas are the seven general capabilities. These capabilities, which are skills, values and dispositions considered essential for students to acquire for the $21^{\text {st }}$ Century, have been incorporated into the curriculum content of learning areas and subject areas, where relevant, based on learning progressions developed for each of the capabilities. The seven capabilities are:

- Literacy;

- Numeracy;

- Information and Communication Technology (ICT) Capability;

- Critical and Creative Thinking;

- Personal and Social Capability;

- Ethical Understanding; and

- Intercultural Understanding.

The third dimension, again embedded in the content of the learning areas, is the Cross-Curriculum Priorities. Three areas were identified as priorities:

- Aboriginal and Torres Strait Islander Histories and Cultures;

- Asia and Australia's Engagement with Asia; and

- Sustainability.

These priorities were seen as having particular relevance based on issues related to reconciliation efforts with Australia's Indigenous peoples, Australia's current and future economic and cultural ties with Asian countries and, as one of the driest continents on Earth, the role Australia needs to play both locally and globally in relation to sustainability.

The resultant interplay of the three dimensions means that Australia now has a national curriculum that both honours traditional disciplinary knowledge and skills while also enabling students to develop the essential skills, values and dispositions required for living and succeeding now and in the future. 
A period of implementation has commenced with English, Mathematics, Science and History being implemented in Australian schools and the states and territories determining their own schedules for when the other learning areas will be introduced.

\section{National Assessment Program ${ }^{4}$}

As stated previously the alignment between the Australian Curriculum content and the testing items used in the National Assessment Program commenced this year. To ensure this process is both credible and accurate close collaboration has been required between assessment experts who develop the test items and subject area experts who possess the relevant disciplinary knowledge. Collaborations of this kind are not easy to achieve and require strong leadership as well genuine respect between the experts for the particular capabilities each bring to the test construction process.

While the benefits of aligning the curriculum to an assessment (testing) program are obvious it may be a surprise to many, particularly those outside of the education sector, that such an alignment is less common than realised. There are many reasons for this but the most common of these include different agencies having the responsibility for developing testing programs to those developing curricula, the time lag between curriculum reform initiatives compared to the annual churn of test item development, and the impact that major international assessment programs, e.g. Trends in International Mathematics and Science Study (Timss) and Programme for International Student Assessment (Pisa), have on what countries choose to focus on through their local testing regimes.

In addition to the alignment between the Australian Curriculum and the national testing program Australia is also currently preparing for a significant change to both how its national tests are undertaken and the nature of the data it will collect from the tests. This change, the move to an online tailored testing platform, presents a number of challenges, which include:

- Ensuring all schools, regardless of location, have access to computer networks capable of handling the technological and bandwidth requirements;

- Building the platform required to store and manage the online testing program;

- Ensuring that each child has equal access to appropriate items, regardless of aural, visual or other disability; and

- Developing a sufficient number of test items to ensure that each student's capabilities can be assessed.

While the challenges listed above are not insignificant, there are many benefits to be realised following the implementation of the initiative. These benefits include:

- The provision of more precise information about each student's capabilities;

${ }_{4}$ http://www.nap.edu.au$$
\text { capabilities; }
$$ 
- A faster turnaround of student performance results and resultant steps that can be taken to better support each student according to their individual learning and development needs;

- Potential reductions in costs over time (through the replacement of paper-based human marking with machine marking of students' responses);

- Greater engagement of students during the testing process owing to the items being more closely aligned to their individual capabilities;

- The creation of large banks of test items which have a potential use beyond the testing program, such as for schools to acquire for their own use; and

- Potential for "on demand" testing in the future owing to the individualised nature of the testing process, enabling tests to be undertaken whenever it is believed an individual is "ready" rather than at a scheduled time in the year.

\section{Reporting}

Another important initiative that has dramatically changed education in Australia in recent times is public access to information about Australian schools. Australia has just over 10,000 schools. This number includes a mix of government schools and non-government schools (inclusive of independent schools and religious-based schools such as systemic Catholic schools).

From 2010 following another agreement reached by the Education Council, information about each school has been made available through the My School ${ }^{5}$. This site includes contextual information about each school, including information about its enrolments, staff numbers, finances (income and expenditure) and the school's most recent Naplan results and its performance compared to like schools. This last feature is particularly interesting as it is based on the comparative performance of schools grouped within the same socio-educational rating. ${ }^{6}$

This transparent mechanism provides schools, parents, schooling authorities and the public with access to information which was previously largely unknown about each school. In addition to some basic information about a school, the data contained on the website provides insight into the progress in students' literacy and numeracy achievement each school is making overtime and how it is performing against schools with students from similar socio-educational backgrounds. This along with other information available on a school's own website provides a comprehensive account from which decisions can be made and conclusions can be drawn.

\section{Senior secondary curriculum and credentialing}

Apart from the development of some subject area curricula developed by Acara for the senior secondary years of schooling (Years 11 and 12),
5 http://www.myschool.edu.au

6 This rating is in accordance with the Index of Community Socio-Educational Advantage (Icsea). Icsea is a measure designed to take into account students' family backgrounds (parents' occupation, school education and nonschool education) as well as geographical circumstances and the number of Aboriginal or Torres Strait Islander students enrolled in the school. Schools across Australia are grouped according to their Icsea rating, enabling comparisons to be made between schools whose students are from similar socio-educational backgrounds. 
the focus for the development of national standards in curriculum and assessment has to date been centred on the first year of school through to Year $10^{7}$. This is largely owing to the time and effort required to adjust the current final year examination systems that operate across Australia to a changed or changing curriculum and the consequential impact on the associated high stakes credentialing processes.

At present the states and territories are utilising the Australian Curriculum developed for the senior secondary years of schooling ${ }^{8}$ as the "common and agreed basis" for the courses offered in their respective jurisdictions in Years 11 and 12.

Each state and territory also has in place its own credential for students to use to signify completion of schooling and attainment. Different systems are used across the country to assess the performance and achievement of students at the end of Year 12 though most involve a mix of external examinations and internally conducted criterion-based assessment processes. Final marks in across the courses in these years in addition to moderation and scaling processes are used as the basis for the credential. This credential then becomes a student's "passport" for use when seeking enrolment in a preferred university course, training college course or for employment.

\section{Quality teaching standards}

A final yet equally important contribution to the standards setting agenda that Australia has undertaken over the last 8 years is the establishment of quality teaching standards. ${ }^{9}$

It is well recognised that quality teaching has a significant effect on student learning and achievement. ${ }^{10}$ In response to this Australia has established teaching standards covering three domains (professional knowledge, professional practice and professional engagement) across four career stages of teaching:

- Graduate - the standard (knowledge and skills) expected of a graduate from a teacher education institute who has completed a teacher education qualification and is entering the profession.

- Proficient - teachers who meet this standard demonstrate the minimal requirements for registration as a teacher.

- Highly Accomplished - teachers who meet this standard are highly effective and skilled practitioners.

- Lead - teachers who meet this standard are recognised as exemplary teachers.

These standards have been taken up by each of the Australian states and territories and they are currently using them as a key component in the registration and accreditation of teachers through their relevant teacher registration authorities. The standards are also being used by schooling 
authorities across the country as the basis for their teacher performance review systems.

In addition to the quality standards for teachers, a standard has also been developed for school principals. ${ }^{11}$ This standard, called the Australian Professional Standard for Principals, has been developed to be used by principals for self-reflection. Through the use of this Standard principals can monitor their own professional growth using a matrix consisting of three leadership requirements: vision and values; knowledge and understanding; and personal qualities, social and interpersonal skills and five professional practices: leading teaching and learning; developing self and others; leading improvement, innovation and change; leading the management of the school; and engaging and working with the community.

As with the other standards, the teaching standards align with those established through the national curriculum and the National Assessment Program. This reinforces the importance placed on establishing clear, cohesive and comprehensive education standards in Australia.

\section{A changed or changing landscape?}

The title of this article suggests that Australia's educational landscape has changed. This is certainly the case.

It is clear that as a result of major policy reforms and initiatives that education in Australia is significantly different now to what it was a decade ago. However, this should not be taken to say that a period of settlement has been reached or that following the significant standards-setting reforms there are no areas where further reform is warranted or desired. There is fertile ground for reform in other areas.

Consideration has been given to a number of additional areas where a national approach might be beneficial. While the commitment to progressing these has varied, the following four areas have been the subject of policy consideration and debate over recent years and could at some time in the future add to the reform agenda:

- The development of additional senior secondary curriculum to provide a full suite of Year 11 and 12 courses based on the existing learning areas in the Australian Curriculum;

- Establishing a national high-stakes exit credential at the end of Year 12 based on a common assessment program;

- Introducing a national senior secondary assessment that provides students, parents and employers with a summary account of the literacy and numeracy skills, knowledge and understanding each student has acquired by the final years of school (essentially extending Naplan to Year 11); and

- Extending population testing/assessment (or at least sample testing/assessment) to other curriculum areas including general

\footnotetext{
$\overline{11}$ http://www.aitsl.edu.au/ australian-professionalstandard-for-principals
} 
capabilities such as intercultural understanding, critical and creative thinking, personal and social capability, and ethical understanding.

The standards-setting reforms that have taken place in Australia have changed the educational landscape forever.

Reaching policy settlements of the kind achieved to date has not been easy. However, the outcome has been worth the effort for it can now be said that: wherever a student is located in Australia they have access to the same high quality curriculum, their achievements and progress can be judged and monitored against levels expected of other Australian students, and their teachers are required to meet the same high quality standards expected of other teachers in Australia.

As a result of the reforms Australia's highly regarded education system has been made stronger and better.

\section{References}

HATTIE, J. Teachers make a difference: what is the research evidence? In: AUSTRALIAN COUNCIL FOR EDUCATIONAL RESEARCH ANNUAL CONFERENCE, 2003, Melbourne. Paper. . Melbourne, Australia: University of Auckland, 2003.

HATTIE, J. Visible learning: a synthesis of over 800 meta-analyses related to achievement. New York: Routledge, 2009.

MARZANO, R. J. Setting the record straight on "high-yield" strategies. Phi Delta Kappan, Arlington, v. 91, n. 1, p. 30-37, sept. 2009

ROWE, K. The importance of teacher quality as a key determinant of students experiences and outcomes of schooling.2003. Available from: $<$ http://research.acer.edu.au/cgi/viewcontent.cgi?article=1001\&context =research_conference_2003>.

Recebido em 4 de julho de 2016.

Aprovado em 30 de setembro de 2016. 